Portland State University

PDXScholar

Economics Faculty Publications and

Presentations

Economics

$2-2012$

\title{
Trilemma Policy Convergence Patterns and Output Volatility
}

Joshua Aizenman

University of California, Santa Cruz

Hiro Ito

Portland State University, ito@pdx.edu

Follow this and additional works at: https://pdxscholar.library.pdx.edu/econ_fac

Part of the Economics Commons

Let us know how access to this document benefits you.

\section{Citation Details}

Aizenman, Joshua, and Hiro Ito. "Trilemma policy convergence patterns and output volatility." The North American Journal of Economics and Finance 23.3 (2012): 269-285.

This Working Paper is brought to you for free and open access. It has been accepted for inclusion in Economics Faculty Publications and Presentations by an authorized administrator of PDXScholar. Please contact us if we can make this document more accessible: pdxscholar@pdx.edu. 
NBER WORKING PAPER SERIES

TRILEMMA POLICY CONVERGENCE PATTERNS AND OUTPUT VOLATILITY

Joshua Aizenman

Hiro Ito

Working Paper 17806

http://www.nber.org/papers/w17806

\author{
NATIONAL BUREAU OF ECONOMIC RESEARCH \\ 1050 Massachusetts Avenue \\ Cambridge, MA 02138 \\ February 2012
}

The views expressed herein are those of the authors and do not necessarily reflect the views of the National Bureau of Economic Research. Hiro Ito gratefully acknowledges the financial support of faculty research funds of Portland State University.

NBER working papers are circulated for discussion and comment purposes. They have not been peerreviewed or been subject to the review by the NBER Board of Directors that accompanies official NBER publications.

(C) 2012 by Joshua Aizenman and Hiro Ito. All rights reserved. Short sections of text, not to exceed two paragraphs, may be quoted without explicit permission provided that full credit, including $\odot$ notice, is given to the source. 
Trilemma Policy Convergence Patterns and Output Volatility

Joshua Aizenman and Hiro Ito

NBER Working Paper No. 17806

February 2012

JEL No. F15,F2,F32,F36,F4

\begin{abstract}
We examine the open macroeconomic policy choices of developing economies from the perspective of the economic "trilemma" hypothesis. We construct an index of divergence of the three trilemma policy choices, and evaluate its patterns in recent decades. We find that the three dimensions of the trilemma configurations are converging towards a "middle ground" among emerging market economies -- managed exchange rate flexibility underpinned by sizable holdings of international reserves, intermediate levels of monetary independence, and controlled financial integration. Emerging market economies with more converged policy choices tend to experience smaller output volatility in the last two decades. Emerging markets with relatively low international reserves/GDP could experience higher levels of output volatility when they choose a policy combination with a greater degree of policy divergence. Yet this heightened output volatility effect does not apply to economies with relatively high international reserves/GDP holding.
\end{abstract}

Joshua Aizenman

Department of Economics; E2

1156 High St.

University of California, Santa Cruz

Santa Cruz, CA 95064

and NBER

jaizen@ucsc.edu

Hiro Ito

Portland State University

1721 SW Broadway, Suite 241

Portland, Oregon 97201

ito@pdx.edu 


\section{Introduction}

A fundamental contribution of the Mundell-Fleming framework is the impossible trinity, or the Trilemma. The Trilemma states that a country may simultaneously choose any two, but not all of the following three policy goals - monetary independence, exchange rate stability and financial integration. Among Mundell's seminal contributions in the 1960s was the derivation of the Trilemma in the context of an open economy extension of the IS-LM Neo-Keynesian model. The model considers a small country choosing its exchange rate regime and its financial integration with the global financial market. Analysis is considerably simplified by focusing on polarized binary choices, i.e., credibly fixed exchange rate or pure float, and prefect capital mobility or financial autarky. ${ }^{1}$ This hypothesis has been widely taught and recognized since it is quite intuitive and helpful to understand the constraints policy makers must face in an open economy setting.

Theory tells us that each one of the three trilemma policy choices can be a double-edged sword, which should explain the wide and mixed variety of empirical findings on each of the three policy choices. Significant recent literature recognized these issues. ${ }^{2}$ To make the matter more complicated, while there are three ways of pairing two out of the three policies, the effect of each policy choice can differ depending on what the other policy choice it is paired with. For example, exchange rate stability can be more destabilizing when it is paired with financial openness while it can be stabilizing if paired with greater monetary autonomy. Hence, it may be worthwhile to empirically analyze the three types of policy combinations in a comprehensive and systematic manner.

Furthermore, countries rarely face the stark polarized binary choices envisioned by the original Trilemma. Instead, countries operate in the range of the 'generalized Trilmma configuration' -- partial financial integration, controlled exchange rate flexibility, and a degree of monetary independence. Understanding these mixed regimes remains a challenge, as there is no unique way to define and measure the degree the three Trilemma variables. Proper modeling of

\footnotetext{
${ }^{1}$ For overview of Mundell's works see The Prize in Economics 1999 - Press Release (http://www.nobelprize.org/nobel_prizes/economics/laureates/1999/press.html) or Mundell (1961, 1963). See Aizenman (2011) for overview of the research dealing with the trilemma.

${ }^{2}$ As for monetary independence, refer to Obstfeld, et al. (2005) and Frankel et al. (2004). On the impact of the exchange rate regime, refer to Ghosh et al. (1997), Levy-Yeyati and Sturzenegger (2003), and Eichengreen and Leblang (2003). The empirical literature on the effect of financial liberalization is surveyed by Edison et al. (2002), Henry (2006), Kose et al. (2006), Prasad et al. (2003), and Prasad and Rajan (2008).
} 
limited financial integration and limited substitutability of assets and testing the Trilemma in a generalized or systematic manner have been still work in progress. Yet, even in this murky situation, the Trilemma remains a potent paradigm since policy makers are challenged by the scarcity of independent policy instruments.

Aizenman, Chinn, and Ito (2008, 2010, 2011) developed a set of the "trilemma indexes" that measure the degree of achievement in each of the three policy choices for a wide coverage of countries and years. They measure the degree to which each of the three policy choices is implemented by economies for more than 170 economies for 1970 through $2007 .^{3}$ The monetary independence index (MI) is based on the correlation of a country's interest rates with the base country's interest rate. The index for exchange rate stability (ERS) is an invert of exchange rate volatility, i.e., standard deviations of the monthly rate of depreciation, using the exchange rate between the home and base economies. The degree of financial integration is measured with the Chinn-Ito $(2006,2008)$ capital controls index (KAOPEN). ${ }^{4}$

Using the indexes, they empirically proved that the hypothesis is valid by showing that the three measures of the trilemma are linearly related to each other. In this paper, using the “trilemma indexes" first introduced in Aizenman, et al. (2008), we focus on characterizing the policy choices based on the trilemma taken by a group of emerging market economies (EMGs). ${ }^{5}$ While developing countries account for more than half of the global GDP, the EMGs composed mostly of middle- to high-income countries (but excluding traditional industrialized countries) with high degrees of trade, and sometimes financial, openness - account for $40 \%$ of the global population and have been growing at a much faster rate than the industrialized countries or other non-emerging market developing countries in the last few decades. Despite oft-observed vulnerabilities due to higher volatility of terms of trade, greater exposure to commodity prices shocks, lower financial depth, and frequently polarized society, the economic performance of these economies has been impressive. That suggests that the benefit of optimal choices of the Trilemma policies must be significant for these economies.

\footnotetext{
${ }^{3}$ The data are updated to 2010 for monetary independence and exchange rate stability and to 2009 for financial openness. The indexes are available at http://web.pdx.edu/ ito/trilemma_indexes.htm.

${ }^{4}$ Refer to Appendix for the details of construction of the indexes. The methodology outlined in these papers has been applied and extended to several studies, including Hutchison, Sengupta, and Singh (2011), Cortuk and Singh (2011), and Popper, Mandilaras, and Bird (2011).

${ }^{5}$ The emerging market countries (EMGs) are defined as the countries classified as either emerging or frontier during the period of 1980-1997 by the International Financial Corporation plus Hong Kong and Singapore.
} 
Among EMGs, we particularly focus on a characteristic of their trilemma policies that have been evident in recent decades. That is the tendency for the "middle-ground convergence" emerging market economies tend to choose a policy combination composed of intermediate levels of all three policies. Using the trilemma indexes, we provide a metric that measures the degree of divergence among the three trilemma policies, and show that the middle-ground convergence tends to be more evident among Asian EMGs. We also provide evidence that a country equipped with intermediate levels of the three trilemma policies tend to experience a lower level of output volatility. That may explain the recent tendency of middle-ground convergence among emerging market economies.

Interestingly, for the emerging market economies, the indexes suggest a convergence toward the middle ground, even as talk of the disappearing middle has been doing the rounds. This pattern of results suggests that emerging market economies may have been trying to cling to moderate levels of both monetary independence and financial openness while maintaining higher levels of exchange rate stability. In other words, they have been leaning somewhat against the trilemma over a period that interestingly coincides with the time when some of these economies began accumulating sizable international reserves (IR), potentially to buffer the trade-off arising from the trilemma. These observations are particularly applicable to Asian EMGs, but not to non-emerging developing market economies. For the latter group of economies, exchange rate stability has been the most aggressively pursued policy throughout the period. In contrast to the experience of the emerging market economies, financial liberalization has not been proceeding rapidly for the non-emerging market developing economies.

\section{The Index of Policy Convergence}

To see how much convergence is taking place, we propose to calculate a new variable that measures the extent of divergence in all three trilemma indexes. The measure of triad policy divergence $d_{i t}$ is calculated as follows:

$$
d_{i t}=\sqrt{\left(m i_{-} r_{i t}-1\right)^{2}+\left(e r s_{-} r_{i t}-1\right)^{2}+\left(k a_{-} r_{i t}-1\right)^{2}}
$$

where $X_{-} r_{i t}=\frac{X_{i t}}{\overline{X_{t}}}$ for $X=M I, E R S$, and KAOPEN, and $\overline{X_{t}}$ is cross-country average of $X$ in year $t$. 
Figure 1 illustrates the average of $d_{i t}$ for different subgroups of countries based on income levels. We can make several interesting observations based on this figure. For the last two decades, advanced economies tend to have combinations of distinctive policies. Not surprisingly, the Euro country group has the highest degree of policy divergence among the country groups, followed by the group of non-Euro advanced economies. The group of emerging market economies has had the lowest degree of policy convergence in the last two decades. Since the beginning of the 1980s, developing economies, whether or not with emerging markets, have had relatively stable movement in the degree of policy convergence except for the mid-1990s when both subgroups of developing economies experienced a drop in the degree of policy divergence. In the crisis years of 1982, 1997-98, and 2008-09 - the Mexican debt crisis, the Asian financial crisis, and the global financial crisis, interestingly, the policy convergence measure tends to fall in the years prior to the crisis years.

To see what is driving the trajectories in Figure 1, we look at the group mean of the ratios of each of the three indexes to its cross-country mean (i.e., $X_{i t} / \bar{X}_{t}$ for monetary policy independence $(M I)$, exchange rate stability $(E R S)$, and financial openness $(K A O P E N))$. ${ }^{6}$ We focus our discussions on developing economies and report the average ratios for emerging market economies and non-emerging market developing economies in Figures 2 and 3, respectively.

These figures show clear differences between emerging market economies and nonemerging market developing economies. First, from the beginning of the sample period through the end of the 1990s, it is exchange rate stability that non-emerging market developing economies have prioritized while emerging market economies have pursued monetary independence during the same period. Second, despite the prevalent anecdotal view that emerging market economies have pursued greater exchange rate stability, it has not been given the first priority over the sample period. Third, most distinctively from the non-emerging market group, emerging market economies have increased the extent of financial openness very rapidly in the last two decades. Fourth, while non-emerging market developing economies increased the extent of monetary independence in the first half of the 2000s, the opposite is true for emerging

\footnotetext{
${ }^{6}$ The cross country average $\left(\bar{X}_{t}\right)$ is the sample average of $\mathrm{X}$ including the industrialized countries for year $t$.
} 
market economies. However, facing the global financial crisis of 2008-09, emerging market economies rapidly regained monetary independence.

We are also curious to see if there are any regional characteristics in the formation of triad open macro policies. Externality can play a role in concerting policy decision makings among neighboring countries in a region while possibly increasing the cost of shying away from regional policy coordination. Furthermore, there can be a regional economic integration such as in the case of East Asian supply chain network or a monetary policy arrangement as in the case of Gulf Cooperation Council (GCC). Hence, comparison among geographical groups of countries should shed another ray of light on the differences in the characteristics of triad open macro policies among countries. Figure 4 illustrates the averages of the policy dispersion measure $\left(d_{i t}\right)$ for different regional country groups.

One interesting observation we can make is that both Asian emerging market economies and countries in the middle-east and northern Africa experienced high levels of policy divergence from the beginning of the 1980s through the early 1990s. This is mainly because the countries in both regional groups achieved higher levels of financial opening compared to the average of developing economies. ${ }^{7}$ More interestingly, since the last few years of the 1990s, which coincides with the Asian Crisis period, the degrees of policy divergence have been persistently small among all regional groups. This policy convergence among developing economies may reflect the great moderation, but the convergence seems to be still in place in the last few years of the sample that corresponds to the years of the global financial crisis. Lastly, despite its high levels of policy divergence in the 1980s, emerging market economies in Asia have been experiencing lowest levels of policy divergence in the last decade. Aizenman, Chinn, and Ito (2011) examined econometrically how the triad open macro policy combinations can affect macroeconomic performances such as output growth and volatility, inflation, and inflation volatility. They concluded that the policy combinations implemented by emerging market economies in Asia have allowed these economies to experience low levels of output volatility. The figures here suggest that the "middle-ground convergence" of the triad open macro policies may also have contributed to the stability of these economies’ output performances.

\footnotetext{
${ }^{7}$ Plus, Latin American countries, many of which went through debt crises, retrenched financial openness around the same period, dragging down the average.
} 


\section{Effect of Policy Convergence}

Given that Asian emerging market economies, as well as developing economies in general, were barely affected by the global financial crisis of 2008-09, the high degree of policy convergence we observe for developing economies, especially emerging market economies, may have also contributed to more stable output performances of developing economies. We focus on this issue in this section.

An economy with its triad open macro policies clustered around the intermediate levels, as is the case with many emerging market economies, may be able to retain stability in its output performance. By avoiding a policy combination of distinctive choices among the three open macro policies, the economy may be able to dampen the negative aspects of each of the three policy choices we discussed in a previous section. If that is true, we can expect smaller $d_{i t}$ 's to be correlated with smaller output volatilities.

Figure 5 displays a scatter diagram for the correlation between five-year standard deviations of per capita output growth (in local currency) and the five-year average of the policy divergence measure $d$ for non-overlapping five-year panels from 1970 through 2009. ${ }^{8}$ The gray triangles are for the group of non-emerging market developing economies whereas the black diamonds are for emerging market economies. Both subsamples have slightly positive correlation coefficients as our prior suggested, but both coefficients are insignificant.

For the last two decades, some of the developing economies have been actively opening up their financial markets. One other prior we can make is that countries may try to have a smaller degree of policy divergence to be prepared for potential negative consequences of financial liberalization. If that is true, more financially open economies may experience smaller output volatility when they adopt a policy combination with smaller policy divergence. Let us see if the data are consistent with this prior.

Figure 6 again illustrates the correlation between output volatility and the measure of policy divergence, but now the sample is divided into two groups: financial open economies and financial closed economies. A country is categorized as a financial open economy if its measure of financial openness is greater than the average of the measure among developing economies in a particular year. Financially open economies are shown in black diamonds and financially

\footnotetext{
${ }^{8}$ The five-year standard deviations of per capita output growth that are above the $99^{\text {th }}$ percentile are considered to be outliers and removed from presentation.
} 
closed economies are in gray triangles. As we suspected, financially open economies have a positive, but insignificant, correlation between output volatility and policy dispersion whereas financially closed economies have a slightly negative, insignificant correlation. The p-value of the positive correlation is now 28\%, much lower than that for the negative correlation.

What if we focus on the time period when developing economies, especially those with emerging markets, have been actively liberalizing financial markets? Figure 7 is a recreation of Figure 5, but we now restrict the sample to the 1990-2009 period. We see a clear difference between emerging market economies and non-emerging market economies. Emerging market economies with lower levels of policy dispersion measure tend to experience lower levels of output volatility - the correlation coefficient is significant with a conventional significance level. Non-emerging market economies, on the other hand, tend to experience higher levels of output volatility if they pursue lower levels of policy dispersion though the correlation coefficient is only marginally significant. It appears that emerging market economies have dealt with financial globalization better than non-emerging market developing economies by having more converged policy combinations.

Figure 8 is a recreation of Figure 6, but focusing on emerging market economies in the 1990-2009 period. Emerging market countries without open financial markets have a significantly positive and high correlation between policy convergence and output volatility while those with open financial markets have an insignificantly positive correlation (with a smaller magnitude). This result can be counter-intuitive for those who believe that an economy can experience a turbulence if it pursues greater financial openness and a more distinctively divergent policy combination.

\section{The Trilemma to The Quadrilemma?}

Open macroeconomic management is never an easy task especially for developing countries. Those economies that have decided to pursue greater financial openness have to be prepared for financial turbulences associated with sudden stops of inflows of capital, capital flights, and deleveraging crises. One byproduct of pursuit for greater financial openness while retaining financial and economic stability is rapid accumulation of international reserves among developing economies. As many researchers have pointed out, developing countries, especially emerging market economies, have increased the amount of international reserves holding 
significantly in recent years. While the international reserves/GDP ratio of industrial countries was overall stable, hovering below 10\%, the reserves/GDP ratio of developing countries increased dramatically, close to tripling in 25 years. By 2007, about two thirds of the global international reserves were held by developing countries. Most of this increase has been in Asia. The most dramatic changes occurred in the China, increasing its reserve/GDP from below 5\% in 1980, to about 50\% in 2009. As has been widely discussed, a rapid increase in international reserves holding, especially in Asia, started in the post-Asian crisis period, suggesting that insurance motives are one of the motivations for developing economies to hold massive international reserves (Aizenman and Marion 2003). ${ }^{9}$

Before financial liberalization became more of a general trend for developing countries in the 1990s, the demand for reserves provided self-insurance almost merely against volatile trade flows. However, as financial liberalization efforts created externality among developing countries, leading to abundant but volatile capital flows across countries, countries started finding a strong need to self-insure against volatile financial flows. By the nature of financial markets, the exposure to rapidly increasing demands for foreign currency triggered by financial volatility, exceeds by a wide margin the one triggered by trade volatility. The East Asian crisis was a watershed event, as it impacted high saving countries with overall balanced fiscal accounts. These countries were viewed as being less exposed to sudden stop events as compared with other developing countries prior to the crisis. With a lag, the affected countries reacted by massive increases in their stock of reserves.

Recent studies validate the importance of "financial factors" as key determinants, in addition to the traditional trade factors, in accounting for increased international reserves/GDP ratios. Indeed, recent research has revealed that the role of financial factors has increased in tandem with growing financial integration. More financially open, financially deep countries, with greater exchange rate stability tend to hold more reserves. Within the emerging market sample, the fixed exchange rate effect is weaker, but financial depth (measured by M2/GDP) is highly significant and growing in importance over time (Cheung and Ito 2009, Obstfeld et al. 2010). Trade openness is the other robust determinant of reserve demand, though its importance

\footnotetext{
${ }^{9}$ These economies also cannot expect stable access to the international financial market to the same extent of advanced economies (Obstfeld, et al. 2009). Further, distaste among developing countries for rescue programs offered by the International Monetary Fund (IMF) since the Asian crisis of 1997-98could have also motivated these economies to be prepared for a rainy day on their own.
} 
seems to have diminished over time (Cheung and Ito 2009). The growing importance of financial factors helps in accounting for a greater share of the international reserves/GDP ratios (Aizenman and Lee 2007). These results are in line with a broader self-insurance view, where reserves provide a buffer both against deleveraging initiated by foreign parties and against the sudden wish of domestic residents to acquire new external assets. That is, developing countries often face "sudden capital flight” (Calvo 1998, 2006; Aizenman and Lee 2007) in the form of “double drains" or "external and internal drains" (Obstfeld, et al. 2009). ${ }^{10}$

All these issues suggest that developing countries may need to manage their open macro policies on the basis of the "quadrilemma" rather than the trilemma.

The "diamond charts" in Figure 9 are useful to trace the changing patterns of the "quadrilemma" configurations. Each country's configuration at a given instant is summarized by a "generalized diamond," whose four vertices measure monetary independence, exchange rate stability, IR/GDP ratio, and financial integration. The origin has been normalized so as to represent zero monetary independence, pure float, zero international reserves, and financial autarky. The panels of figures summarize the trends for industrialized economies, emerging Asian economies, non-emerging market developing Asian economies, non-Asian developing economies, and Latin American emerging market economies in the last four decades.

In Figure 9, we can observe again the divergence of the trilemma configurations for the industrial economies over the years-a move toward deeper financial integration, greater exchange rate stability, and weaker monetary independence-while reducing the level of IR holding over years. Asia, especially those economies with emerging markets, appears distinct from other groups of economies; the middle-ground convergence observed for the emerging market group is quite evident for this particular group of economies. This is not a recent phenomenon for the Asian emerging market economies, however. Since as early as the 1980s, the three indexes have been clustered around the middle range, though exchange rate stability has been the most pervasive policy choice and the degree of monetary independence has been gradually declining. This characterization is not applicable to the other groups of developing economies such as Latin American emerging market economies. Most importantly, the group of Asian emerging market economies stands out from the others with their sizeable and rapidly

\footnotetext{
${ }^{10}$ The high positive co-movement of international reserves and M2 is consistent with the view that the greatest capital flight risks are posed by the most liquid assets, i.e., by the liquid liabilities of the banking system as measured by M2 (Cheung and Ito, 2009).
} 
increasing amount of IR holding, making one suspect potential implications of such IR holdings on trilemma policy choices and macroeconomic performances.

Aizenman, et al. (2010) empirically show that pursuing greater exchange stability can be increasing output volatility for developing economies, but that that can be mitigated by holding a greater amount of international reserves than the threshold of about 20\% of GDP. Aizenman, et al. (2011) find that Asian emerging market economies seem to have adopted a policy combination of the three trilemma policies and international reserves that allow these economies to lessen output volatility through reduced real exchange volatility. Given most of Asian emerging market economies are quite open to international trade, implementing a set of open macro policies that helps reduce the volatility of real exchange rates is quite important. ${ }^{11}$ Thus, it is not surprising for developing economies to have become active in accumulating international reserves in recent years.

Let us now examine the impact of holding international reserves in the context of policy convergence. Figure 10 again displays a scatter diagram for the correlation between output volatility and the measure of policy divergence for emerging market economies in the 1990-2009 period. The sample is divided into two subgroups: one composed of emerging market economies that hold international reserves more than the annual median level among developing countries and the other of those economies with reserves lower than the median. Those emerging market economies with lower levels of international reserves have a significantly positive correlation while those with higher levels of reserves have an insignificantly negative association. One interpretation of this result is that holding high levels of international reserves may give countries a wider choice for the degree of policy divergence. For countries with low international reserves, it is better to have a more convergence, but high reserve holders do not face the same kind of trade-off.

What if we restrict the sample to those emerging market economies that have more open financial markets? Figure 11 is the same as Figure 10, except that the sample is now restricted to only emerging market economies with more open financial markets (“open” as defined in Figure

\footnotetext{
${ }^{11}$ More particularly, Aizenman, et al. (2011) also show that an emerging market economy pursuing greater exchange rate stability and greater financial openness (i.e., weaker monetary independence) while holding a massive amount of IR (exceeding 15-20\% of GDP) can experience higher volatility in investment but lower volatility in real exchange rates. However, for economies that are more open to trade, the benefit of lower real exchange rate volatility outweigh the cost of higher investment volatility, signifying the importance of holding massive international reserves.
} 
6). The figures illustrates that emerging market economies with more open financial markets may face higher levels of output volatility if they pursue higher degrees of policy divergence but do not hold high levels of international reserves, though the positive association is not statistically significant. For emerging market economies with more open financial markets and high levels of international reserves, the level of policy divergence does not seem to have an effect on output volatility levels.

Having seen these results, we can conclude not only that the tendency for emerging market economies to have more converged policy combinations help them to experience lower levels of output volatility, but also that holding a higher level of international reserves may help them to get prepared for a future choice of policies that are more distinctively different from each other.

Now that we know holding high levels of IR may allow countries to have a wider range of policy divergence than those without and may help those with wider policy divergence to avoid experiencing higher output volatility, we wonder how emerging market economies performed during the global financial crisis of 2008-09. Although the epicenter of the crisis was not in any emerging market economies but in the advanced economies (mostly the United States), emerging market economies could have been exposed to contagion from the crisis. However, except for a few emerging market economies in Eastern Europe, most of emerging market economies were barely affected by the crisis. In such circumstances, we wonder what was the role of international reserves holding for emerging market economies.

Figures 12 and 13 are helpful to answer this question. Figure 12 shows the correlation between output volatility and the degree of policy divergence for the group of emerging market economies but only for the five-year period of 2005 through 2009 which correspond to the years prior to and during the global financial crisis. In the figure, we see again that the correlation is weaker for the countries that hold higher levels of international reserves - while the correlation is significantly positive for the low IR holders with a conventional significance level, that for the high IR holders is small and insignificant. ${ }^{12}$

The effect of holding IR should be greater for those economies with more open financial markets. Hence, we restrict our sample to only those economies with more open financial markets (as defined previously) and show the result in Figure 13. The result is clear; those

\footnotetext{
${ }^{12}$ The result is independent of whether or not Lithuania, a clear outlier with its high output volatility, is included.
} 
economies which do not hold high levels of IR experienced higher levels of output volatility if they have trilemma policy combinations with a greater degree of divergence. ${ }^{13}$ The high IR holders on average do not face such a positive correlation. Compared to Figure 12, the magnitude of the correlation is higher, suggesting that countries with more open financial markets and higher degrees of policy divergence would have to face higher levels of output volatility if they do not hold high levels of IR. With these results, high levels of IR holding may be one of the reasons for emerging market economies to be able to avoid contagion from the outbreak of the global financial crisis.

\section{Concluding Remarks}

We have examined the development of open macroeconomic policy choices among developing economies from the perspective of the powerful hypothesis of the "trilemma" - a country may not simultaneously pursue the full extent of achievement in all of the three policy goals of monetary independence, exchange rate stability, and financial openness. Using the metrics introduced by Aizenman, Chinn, and Ito (2010), or the "trilemma indexes," that measure the extent of achievement in each of the three policy choices, we have observed several interesting characteristics of the international monetary system.

There are striking differences in the choices that industrialized and developing countries have made over the 1970-2009 period. More importantly, recent trends suggest that among emerging market countries, i.e., those countries that are not traditional advanced countries but with middle or high levels of income and are open to international trade, the three dimensions of the trilemma configurations are converging towards a "middle ground" with managed exchange rate flexibility, underpinned by sizable holdings of international reserves, and intermediate levels of monetary independence and financial integration. Industrialized countries, on the other hand, have been experiencing divergence of the three dimensions of the trilemma and moved toward the combination of higher exchange rate stability and financial openness and low monetary independence (most clearly exemplified by the advent of the euro).

We also focused on the characteristics of the "middle-ground convergence" among emerging market economies. When we examined the correlation between the measure of policy

\footnotetext{
${ }^{13}$ Again, the positive correlation is significant irrespective of Lithuania.
} 
divergence and the level of output volatility, we found that emerging market economies with more converged policy choices tend to experience smaller output volatility in the last two decades. In a world with rapidly proceeding financial globalization, financial liberalization can be a risky policy for developing economies, raising the importance of holding a large amount of international reserves as it has happened in the last decade. On that issue, we found some evidence that emerging markets with low levels of international reserves holding could experience higher levels of output volatility when they choose a policy combination with a greater degree of policy divergence while it does not apply to economies with high levels of international reserves holding. This result may indicate that holding a high volume of international reserves may give room to emerging market economies to choose a policy combination from a wider spectrum of policy combinations.

We also found that this generalization is also true for emerging market economies during the period around the global financial crisis of 2008-09. In the 2005-09 period, economies with high levels of IR holding do not seem to have faced the positive correlation between policy divergence and output volatility while the correlation is quite evident for those economies which did not hold high levels of IR. These results may indicate that high levels of IR holding may be one of the reasons for emerging market economies to be able to avoid contagion from the outbreak of the global financial crisis. 


\section{Appendix: Construction of the Trilemma Indexes}

\section{Monetary Independence (MI)}

The extent of monetary independence is measured as the reciprocal of the annual correlation between the monthly interest rates of the home country and the base country. ${ }^{14}$ Money market rates are used for the calculation. ${ }^{15}$

The index for the extent of monetary independence is defined as:

$$
M I=1-\frac{\operatorname{corr}\left(i_{i}, i_{j}\right)+1}{2}
$$

where $i$ refers to home countries and $j$ to the base country. By construction, the maximum value is 1 , and the minimum value is 0 . Higher values of the index mean more monetary policy independence. ${ }^{16,17}$

Here, the base country is defined as the country that a home country's monetary policy is most closely linked with as in Shambaugh (2004). The base countries are Australia, Belgium, France, Germany, India, Malaysia, South Africa, the United Kingdom, and the United States. For the countries and years for which Shambaugh's data are available, the base countries from his work are used, and for the others, the base countries are assigned based on the International Monetary Fund's Annual Report on Exchange Arrangements and Exchange Restrictions (AREAER) and Central Intelligence Agency Factbook.

\section{Exchange Rate Stability (ERS)}

To measure the extent of exchange rate stability, annual standard deviations of the monthly exchange rate between the home country and the base country are calculated and included in the following formula to normalize the index between 0 and 1 :

\footnotetext{
${ }^{14}$ The base country is defined as the country that a home country's monetary policy is most closely linked with, as defined in Shambaugh (2004). The base countries are Australia, Belgium, France, Germany, India, Malaysia, South Africa, the U.K., and the U.S. For the countries and years for which Shambaugh's data are available, the base countries from his work are used, and for the others, the base countries are assigned based on IMF's Annual Report on Exchange Arrangements and Exchange Restrictions (AREAER) and CIA Factbook.

${ }^{15}$ The data are extracted from the IMF's International Financial Statistics (60B..ZF...). For the countries whose money market rates are unavailable or extremely limited, the money market data are supplemented by those from the Bloomberg terminal and also by the discount rates $(60 . . . Z F . .$.$) and the deposit rates (60L..ZF...) series from IFS.$ ${ }^{16}$ The index is smoothed out by applying the 3-year moving averages encompassing the preceding, concurrent, and following years $(t-1, t, t+1)$ of observations.

${ }^{17}$ We note one important caveat about this index. Among some countries and in some years, especially early ones, the interest rate used for the calculation of the MI index is often constant throughout a year, making the annual correlation of the interest rates between the home and base countries $\left(\operatorname{corr}\left(i_{i}, i_{j}\right)\right.$ in the formula) undefined. Since we treat the undefined corr the same as zero, it makes the MI index value 0.5. One may think that the policy interest rate being constant (regardless of the base country's interest rate) is a sign of monetary independence. However, it can reflect the possibilities not only that (i) the home country's monetary policy is independent from the base country's; but also (ii) the home country uses other tools to implement monetary policy than manipulating the interest rates, such as changing the required reserve ratios and providing some window guidance (while leaving the policy interest rate unchanged); and/or that (iii) the home country implements a strong control on financial intermediary, including credit rationing, that makes the policy interest rate appear constant. To make the matter more complicated, some countries have used (ii) and (iii) to exercise monetary independence while others have used them while strictly following the base country's monetary policy. The bottom line is that it is impossible to incorporate these issues in the calculation of MI without over- or under-estimating the degree of monetary independence. Therefore, assigning an MI value of 0.5 for such a case should be a reasonable compromise.
} 


$$
E R S=\frac{0.01}{0.01+\operatorname{stdev}(\Delta(\log (\text { exch_rate }))}
$$

Merely applying this formula can easily create a downward bias in the index, that is, it would exaggerate the "flexibility" of the exchange rate especially when the rate usually follows a narrow band, but is de- or revalued infrequently. ${ }^{18}$ To avoid such downward bias, we also apply a threshold to the exchange rate movement as has been done in the literature. That is, if the rate of monthly change in the exchange rate stayed within +/-0.33 percent bands, we consider the exchange rate is "fixed" and assign the value of one for the ERS index. Furthermore, single year pegs are dropped because they are quite possibly not intentional ones. ${ }^{19}$ Higher values of this index indicate more stable movement of the exchange rate against the currency of the base country.

\section{Financial Openness/Integration (KAOPEN)}

Without question, it is extremely difficult to measure the extent of capital account controls. ${ }^{20}$ Although many measures exist to describe the extent and intensity of capital account controls, it is generally agreed that such measures fail to capture fully the complexity of real-world capital controls. Nonetheless, for the measure of financial openness, we use the index of capital account openness, or KAOPEN, by Chinn and Ito (2006, 2008). KAOPEN is based on information regarding restrictions in the International Monetary Fund's Annual Report on Exchange Arrangements and Exchange Restrictions (AREAER). Specifically, KAOPEN is the first standardized principal component of the variables that indicate the presence of multiple exchange rates, restrictions on current account transactions, on capital account transactions, and the requirement of the surrender of export proceeds. ${ }^{21}$ Since KAOPEN is based on reported restrictions, it is necessarily a de jure index of capital account openness (in contrast to de facto measures such as those in Lane and Milesi-Ferretti [2002, 2007]). The choice of a de jure measure of capital account openness is driven by the motivation to look into policy intentions of the countries; $d e$ facto measures are more susceptible to other macroeconomic effects than solely policy decisions with respect to capital controls.

The Chinn-Ito index is normalized between zero and one. Higher values of this index indicate that a country is more open to cross-border capital transactions. The index is originally available for 181 countries for 1970 through 2006, and now updated to 2010. The data set we examine does not include the United States because we consider the United States is the "Nth" country.

\footnotetext{
${ }^{18}$ In such a case, the average of the monthly change in the exchange rate would be so small that even small changes could make the standard deviation big and thereby the ERS value small.

19 The choice of the $+/-0.33$ percent bands is based on the $+/-2 \%$ band based on the annual rate, that is often used in the literature. Also, to prevent breaks in the peg status due to one-time realignments, any exchange rate that had a percentage change of 0 in 11 out of 12 months is considered fixed. When there are two re/devaluations in 3 months, then they are considered to be one re/devaluation event, and if the remaining 10 months experience no exchange rate movement, then that year is considered to be the year of fixed exchange rate. This way of defining the threshold for the exchange rate is in line with the one adopted by Shambaugh (2004).

20 See Chinn and Ito (2008), Edison and Warnock (2001), Edwards (2001), Edison et al. (2002), Henry (2007), and Kose et al. (2006) for discussions and comparisons of various measures on capital restrictions.

${ }^{21}$ This index is described in greater detail in Chinn and Ito (2008).
} 


\section{References:}

Aizenman, J. 2011. “The Impossible Trinity - from the Policy Trilemma to the Policy Quadrilemma,” mimeo, University of California, Santa Cruz.

Aizenman, J., M. D. Chinn and H. Ito. 2011. Surfing the Waves of Globalization: Asia and Financial Globalization in the Context of the Trilemma, Journal of the Japanese and International Economies, vol. 25(3), p. 290 320.

Aizenman, J., M. D. Chinn and H. Ito. 2010. The Emerging Global Financial Architecture: Tracing and Evaluating the New Patterns of the Trilemma's Configurations, Journal of International Money and Finance, Vol. 29, No. 4, p. 615-641.

Aizenman, J., M.D. Chinn, and H. Ito. 2008. “Assessing the Emerging Global Financial Architecture: Measuring the Trilemma's Configurations over Time.” NBER Working Paper Series, \#14533 (December).

Aizenman, J. and Lee, J. 2007. International reserves: precautionary versus mercantilist views, theory and evidence, Open Economies Review, 2007, 18 (2), pp. 191-214.

Aizenman, J. and Marion, N. 2004. International reserves holdings with sovereign risk and costly tax collection. Economic Journal 114, pp. 569-91.

Calvo, G. 1998. Capital Flows and Capital-market Crises: The Simple Economics of Sudden Stops. Journal of Applied Economics 1: 35-54.

Calvo, G. 2006. Monetary Policy Challenges in Emerging Markets: Sudden Stop, Liability Dollarization, and Lender of Last Resort. Working Paper 12788, National Bureau of Economic Research.

Cheung, Y. W, and H. Ito. 2009. Cross-sectional analysis on the determinants of international reserves accumulation. International Economic Journal (23) 4: 447-481.

Chinn, M. D. and H. Ito. 2008. A New Measure of Financial Openness. Journal of Comparative Policy Analysis, Volume 10, Issue 3 (September), p. 309 - 322.

Chinn, M. D. and H. Ito, 2006. What Matters for Financial Development? Capital Controls, Institutions, and Interactions, Journal of Development Economics, Volume 81, Issue 1, Pages 163-192 (October).

Cortuk, O. and N. Singh. 2011. Turkey's trilemma trade-offs: is there a role for reserves? Manuscript.

Edison, Hali J., M. W. Klein, L. Ricci, and T. Sløk. 2002. Capital Account Liberalization and Economic Performance: A Review of the Literature. IMF Working Paper. Washington, D.C: IMF.

Edison, Hali J. and F. E. Warnock, 2001. “A simple measure of the intensity of capital controls,” International Finance Discussion Paper \#708 (Washington, D.C.: Board of Governors of the Federal Reserve System).

Edwards, S. 2001. “Capital Mobility and Economic Performance: Are Emerging Economies Different?” NBER Working Paper No. 8076.

Eichengreen, B. and D. Leblang. 2003. Exchange Rates and Cohesion: Historical Perspectives and PoliticalEconomy Considerations. Journal of Common Market Studies, 41(5): 797-822.

Frankel, J.A., S.L. Schmukler, and L. Serven. 2004. “Global Transmission of Interest Rates: Monetary Independence and Currency Regime,” Journal of International Money and Finance, 2004, v23(5,Sep), 701733. 
Ghosh, A., A. Gulde and J. Ostry. 1997. Does the Nominal Exchange Rate Regime Matter? NBER Working Paper No 5874 .

Peter Blair H. 2007. “Capital Account Liberalization: Theory, Evidence, and Speculation,” Journal of Economic Literature, vol. 45(4), p. 887-935 (December).

Hutchison, M., Sengupta, R., and Singh, N., 2011. India’s Trilemma: Financial Liberalization, Exchange Rates and Monetary Policy, forthcoming, The World Economy.

Henry, P. B. 2006. Capital Account Liberalization: Theory, Evidence, and Speculation. NBER Working Paper No. 12698.

Kose, M. A., E. Prasad, K. Rogoff, and S. J. Wei, 2006, Financial Globalization: A Reappraisal. IMF Working Paper, WP/06/189. Washington, D.C.: International Monetary Fund.

Lane, P.R. and G.M. Milesi-Ferretti. 2002. “External wealth, the trade balance, and the real exchange rate,” European Economic Review, vol. 46(6), p. 1049-1071 (June).

Lane, P., and G. M. Milesi-Ferretti. 2007. “The External Wealth of Nations Mark II: Revised and Extended Estimates of Foreign Assets and Liabilities, 1970 - 2004. Journal of International Economics, vol. 73(2), p. 223-250 ( November).

Levy-Yeyati, E. and F. Sturzenegger. 2003. To float or to fix: Evidence on the impact of exchange rate regimes on growth. The American Economic Review 93(4): 1173-1193.

Mundell, R. A. 1963. "Capital mobility and stabilization policy under fixed and flexible exchange rates". Canadian Journal of Economic and Political Science 29 (4): 475-485.

Mundell, R.A. 1961. “A Theory of Optimum Currency Areas”, American Economic Review 51: 657-665.

Obstfeld, M., Shambaugh, J. C. and Taylor, A. M. 2010. Financial Stability, the Trilemma, and International Reserves. American Economic Journal: Macroeconomics (2): 57-94.

Obstfeld, M., J.C. Shambaugh, and A.M. Taylor. 2009. “Financial Instability, Reserves, and Central Bank Swap Lines in the Panic of 2008.” NBER Working Papers 14826. Cambridge, MA : National Bureau of Economic Research (March).

Obstfeld, M., J. C. Shambaugh, and A. M. Taylor, 2005. “The Trilemma in History: Tradeoffs among Exchange Rates, Monetary Policies, and Capital Mobility." Review of Economics and Statistics 87 (August): 423-38.

Popper H., A. Mandilaras, and G. Bird, 2011, Trilemma Stability and International Macroeconomic Archetypes, manuscript, Santa Clara University.

Prasad, E. S. and R. Rajan. 2008. A Pragmatic Approach to Capital Account Liberalization. NBER Working Paper \#14051. (June).

Prasad, E.S., K. Rogoff, S. J. Wei, and M. A. Kose. 2003. “Effects of Financial Globalization on Developing Countries: Some Empirical Evidence.” Occasional Paper 220. Washington, D.C.: IMF.

Shambaugh, Jay C. 2004. “The Effects of Fixed Exchange Rates on Monetary Policy.” Quarterly Journal of Economics 119 (February): 301-52. 
Figure 1: Degree of Policy Dispersions among Different Income Groups of Countries

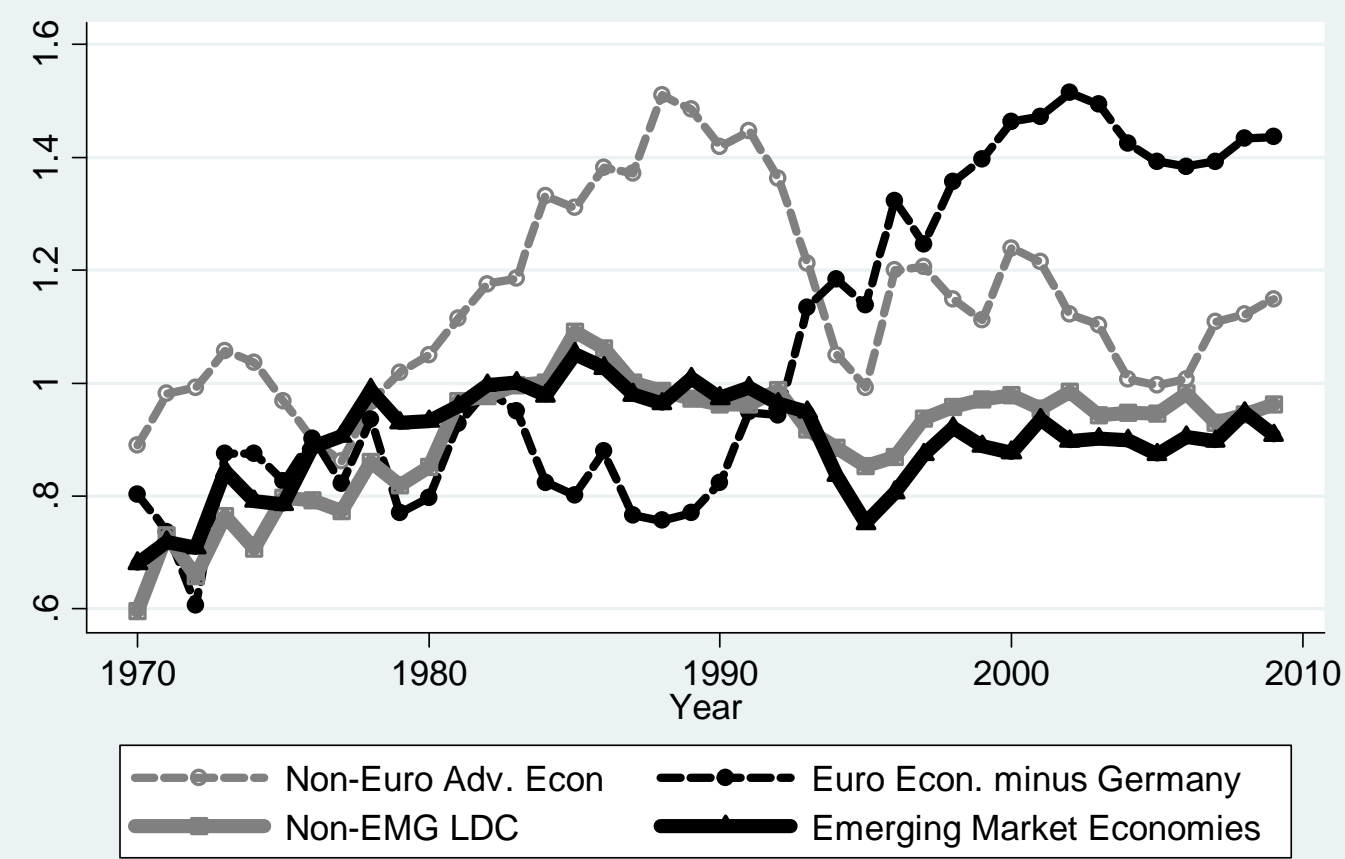

Note: 'Euro economies' include Austria, Beligium, France, Italy, Netherlands, Finland, Greece, Ireland, Portugal, and Spain 
Figure 2: Deviations from the Means - Emerging Market Economies

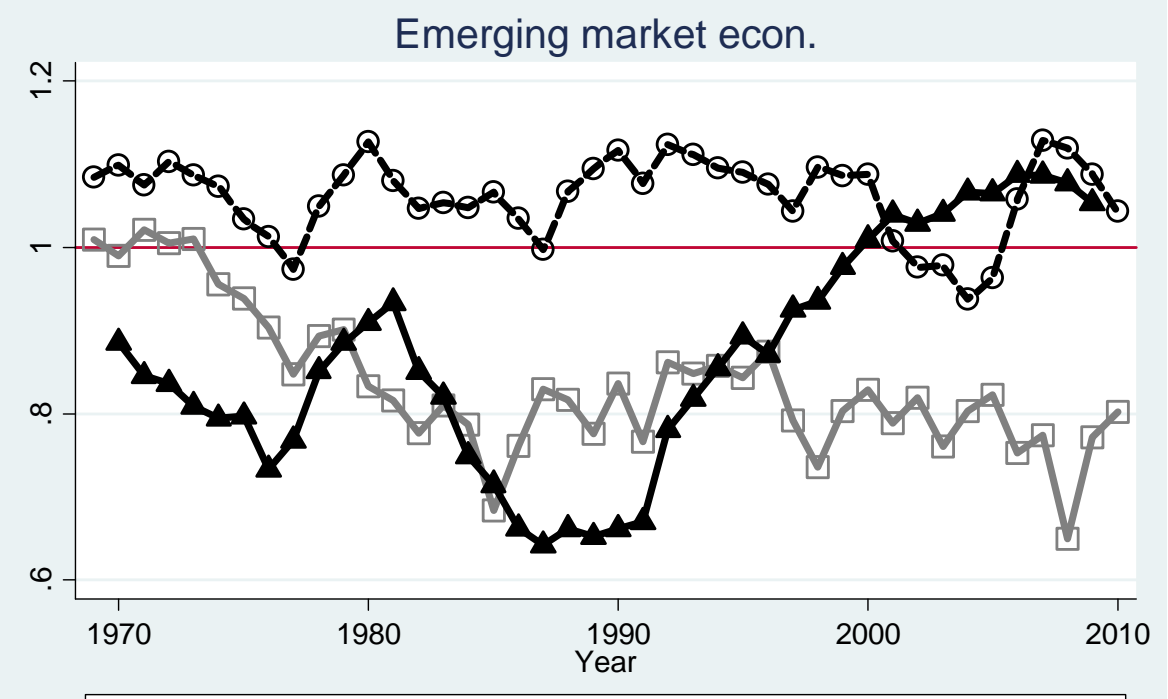

- Monetary Independence, dev. ratio- Exchange Rate Stability, dev. ratio Financial Openness, dev. ratio

Figure 3: Deviations from the Means - Non-Emerging Market Developing Economies

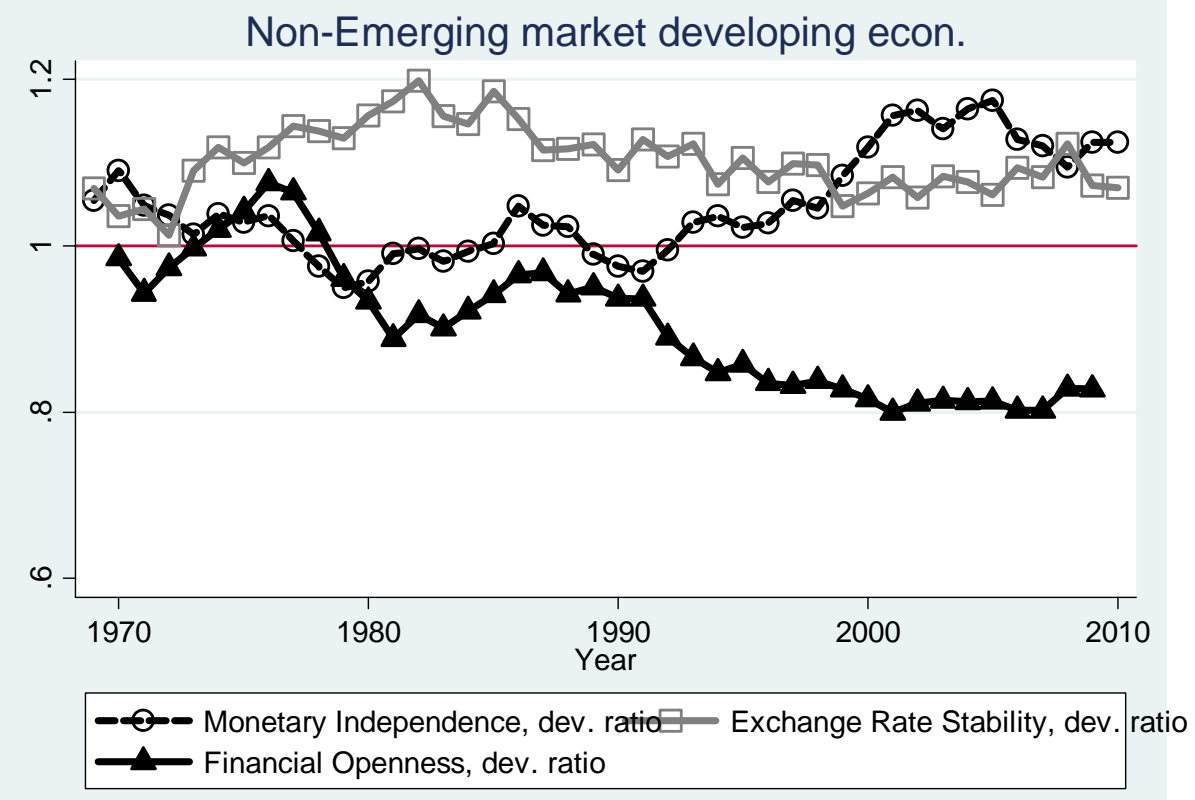


Figure 4: Degree of Policy Dispersions among Different Regional Country Groups

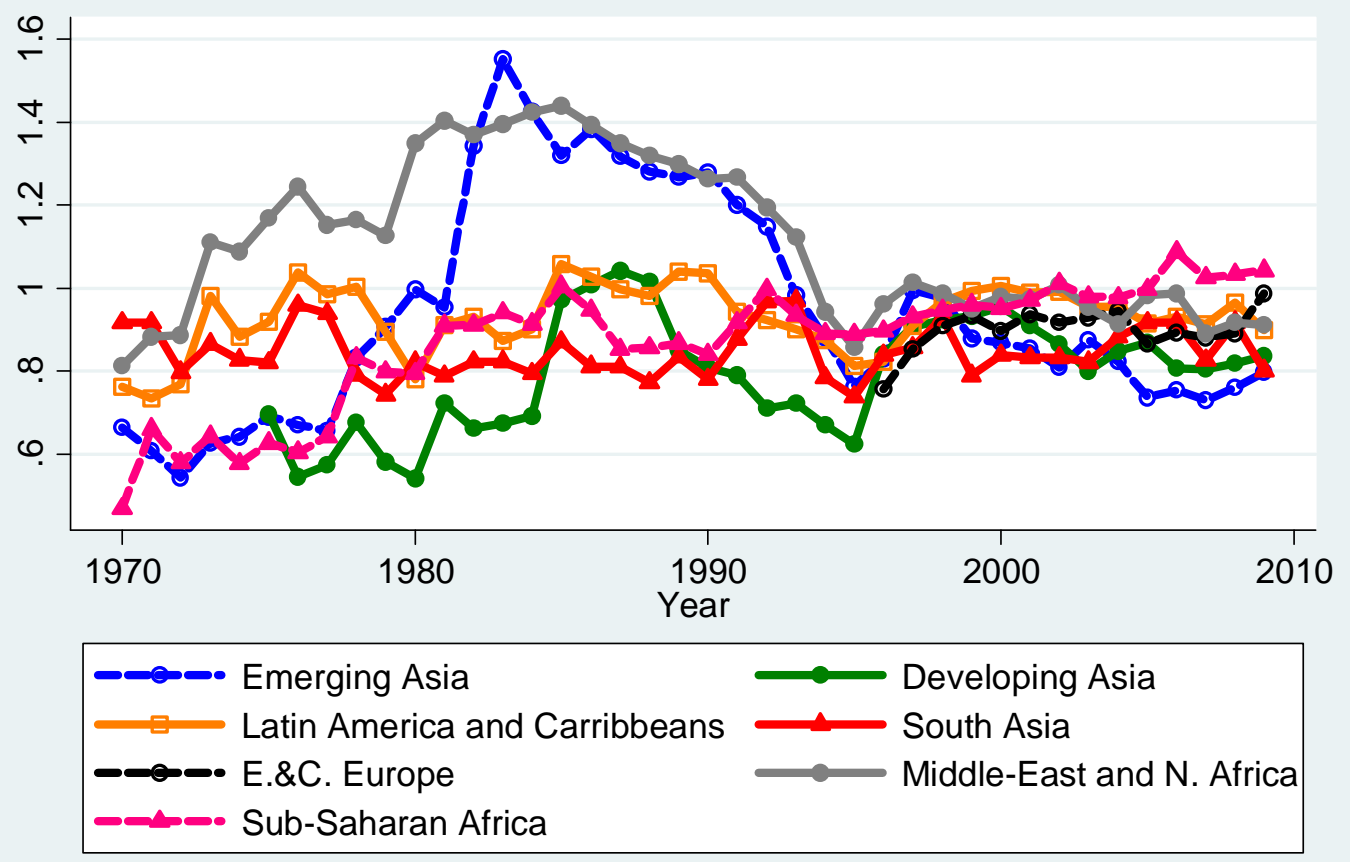

Note: 'Emerging Asia' include China, Hong Kong, Korea, Indonesia, Thailand, Malaysia, Philippines, and Singapore 
Figure 5: Correlations between Policy Dispersion and Output Volatility: EMG vs. Non-EMG

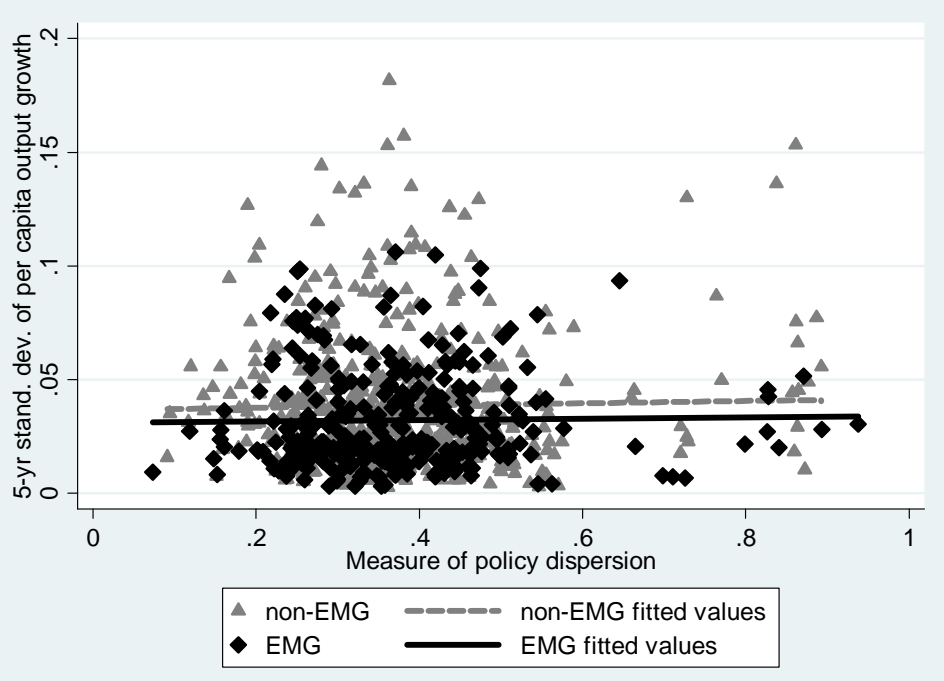

Figure 6: Correlations between Policy Dispersion and Output Volatility: Financially Open vs. Not Open

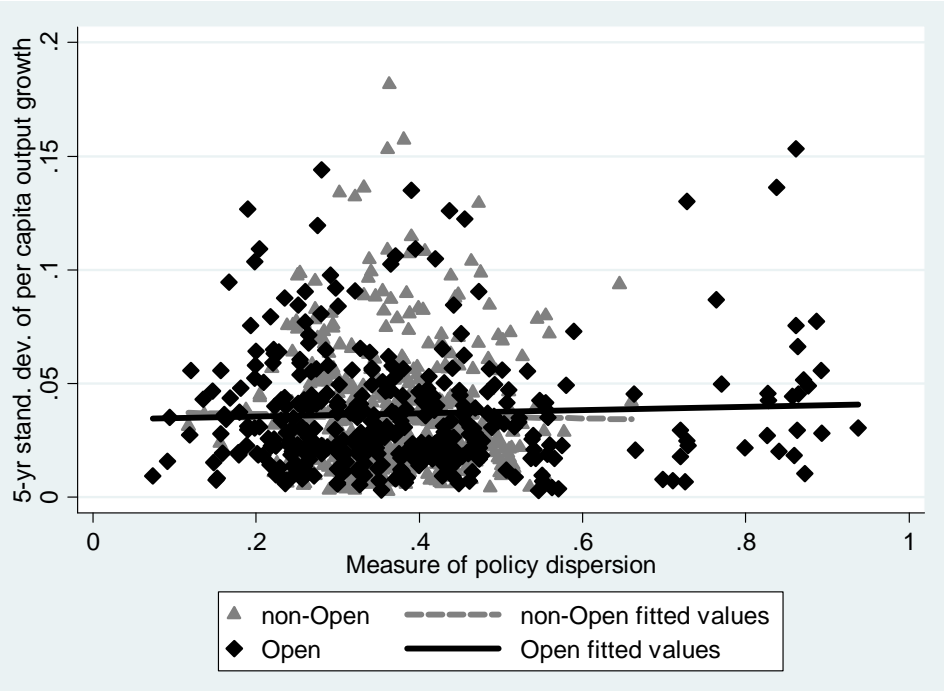

Figure 7: Correlations between Policy Dispersion and Output Volatility: EMG vs. Non-EMG since 1990

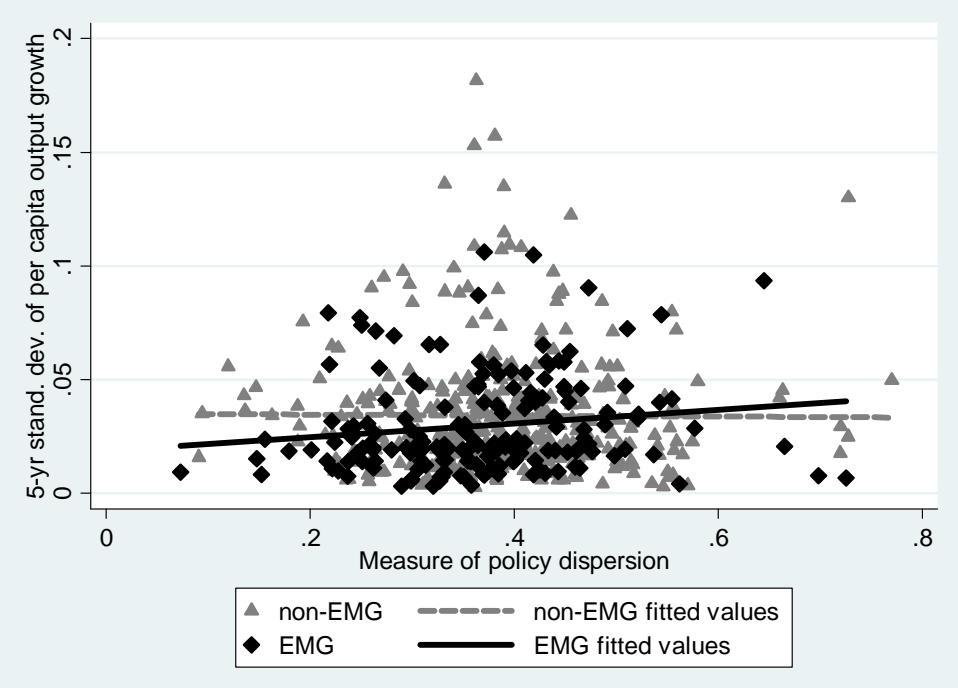

Figure 8: Financially Open vs. Not Open Since 1990

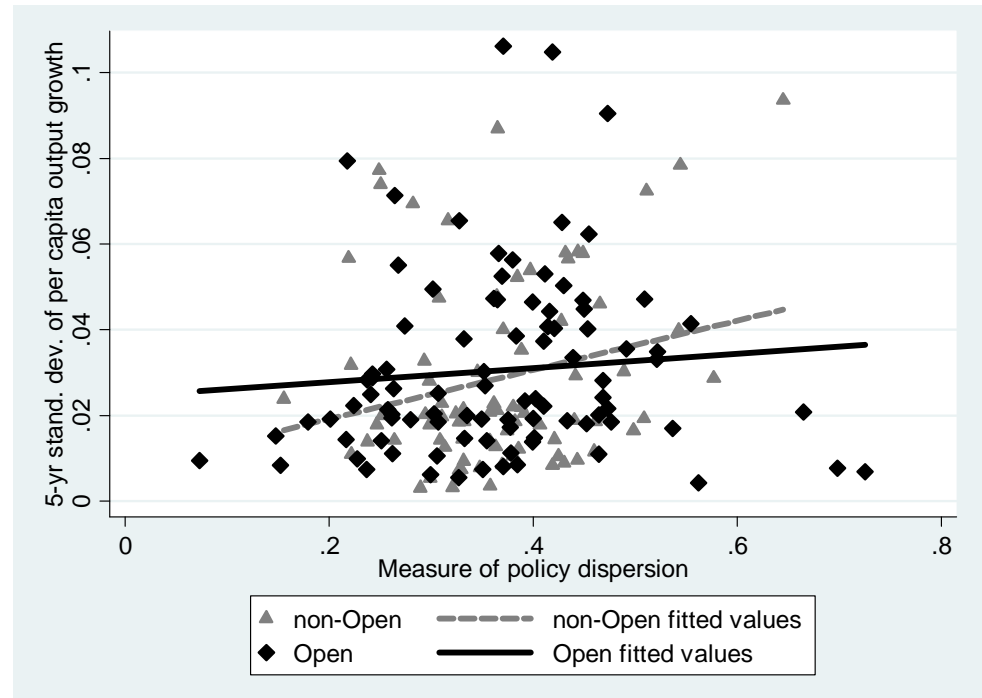


Figure 9: The "Diamond Charts”: Variation of the “Quadrilemma” Across Different Country Groups
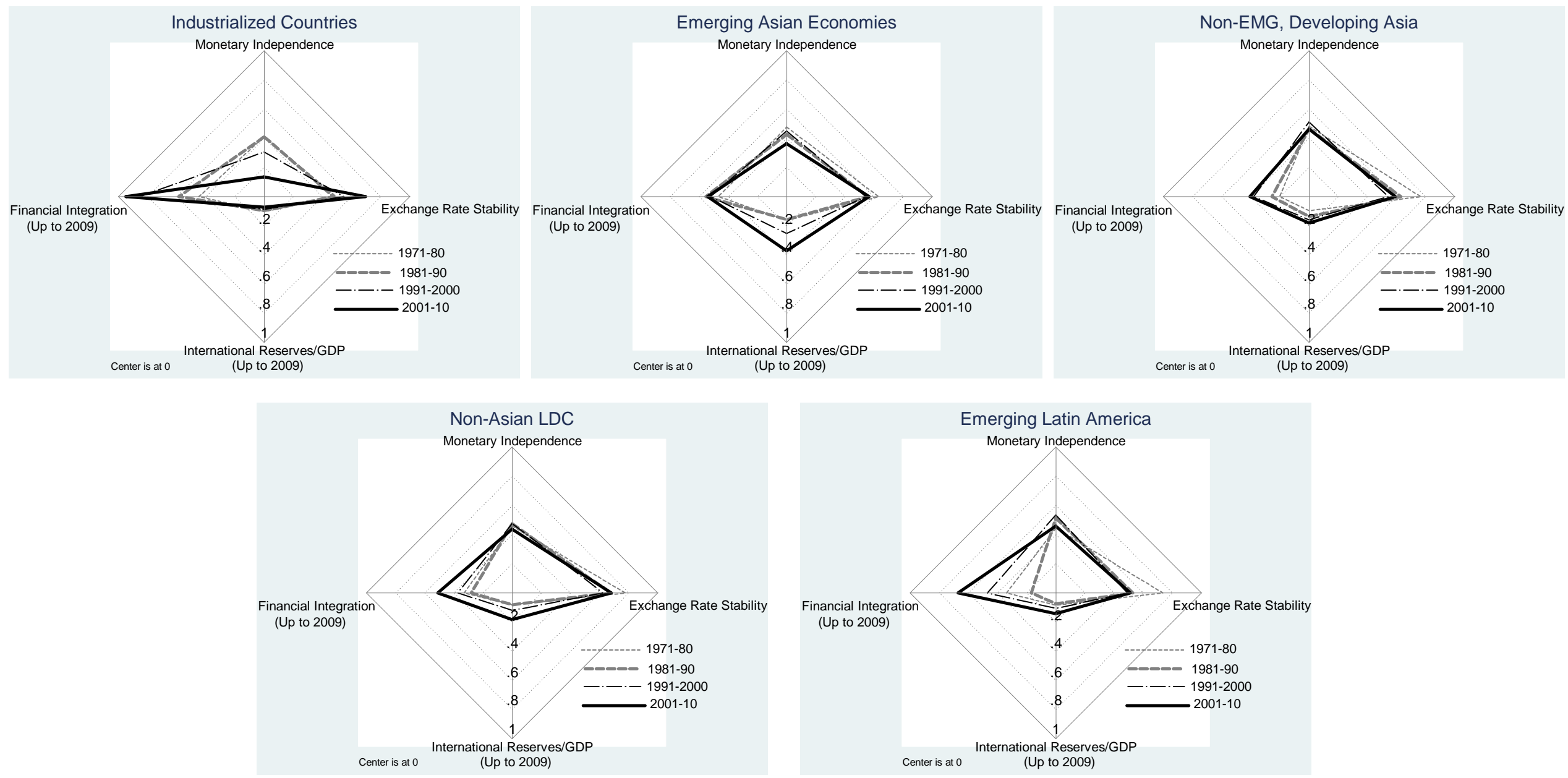
Figure 10: EMGs with and without High IR Holding since 1990

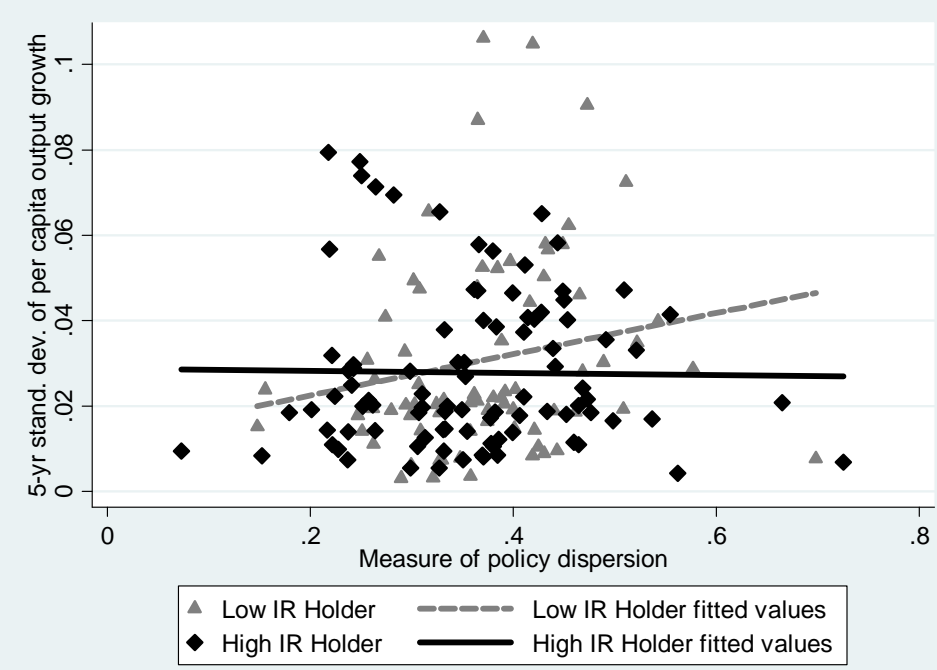

Figure 11: EMGs w/ Open Financial Markets and High IR Holding vs. those w/ Open Financial Market, but w/ Low IR Holdings

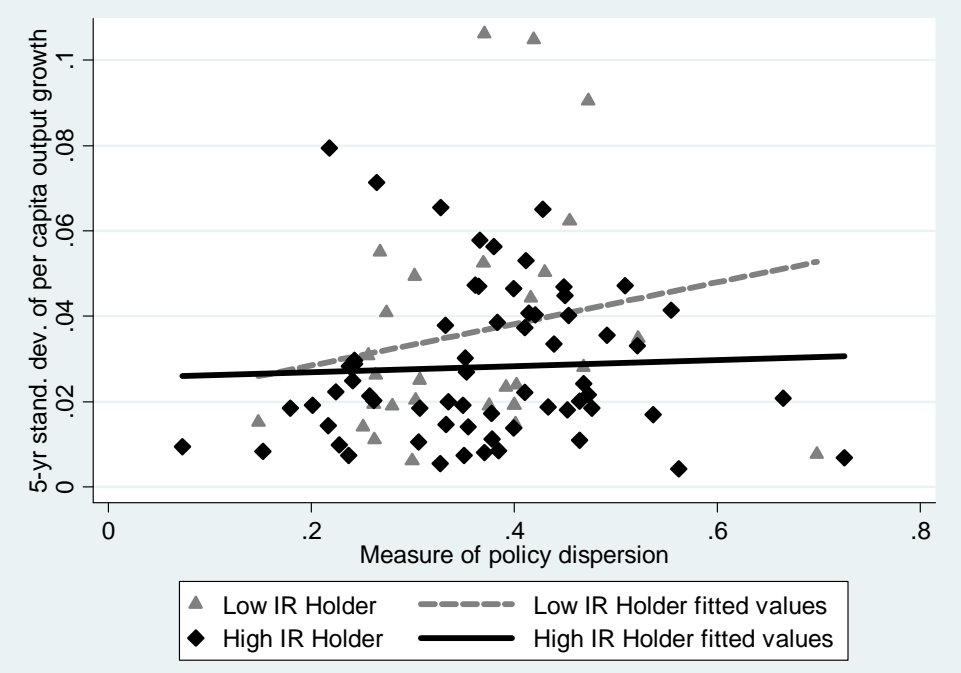

Figure 12 : EMGs with and without High IR Holding in 2005-09

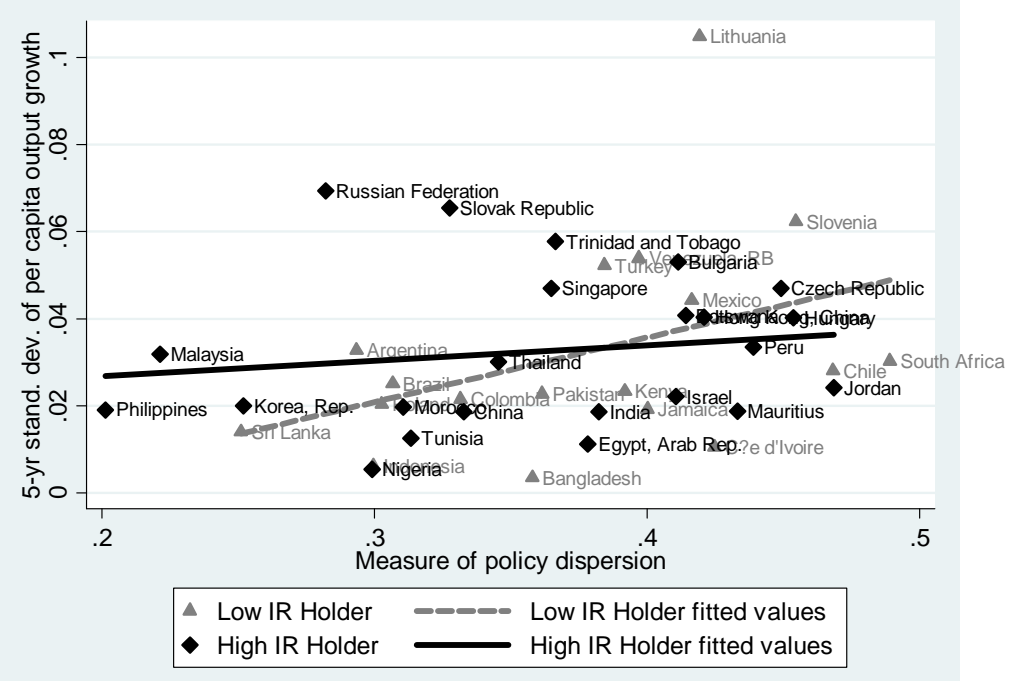

Figure 13 : EMGs with Open Financial Markets and with and without High IR Holding in 2005-09

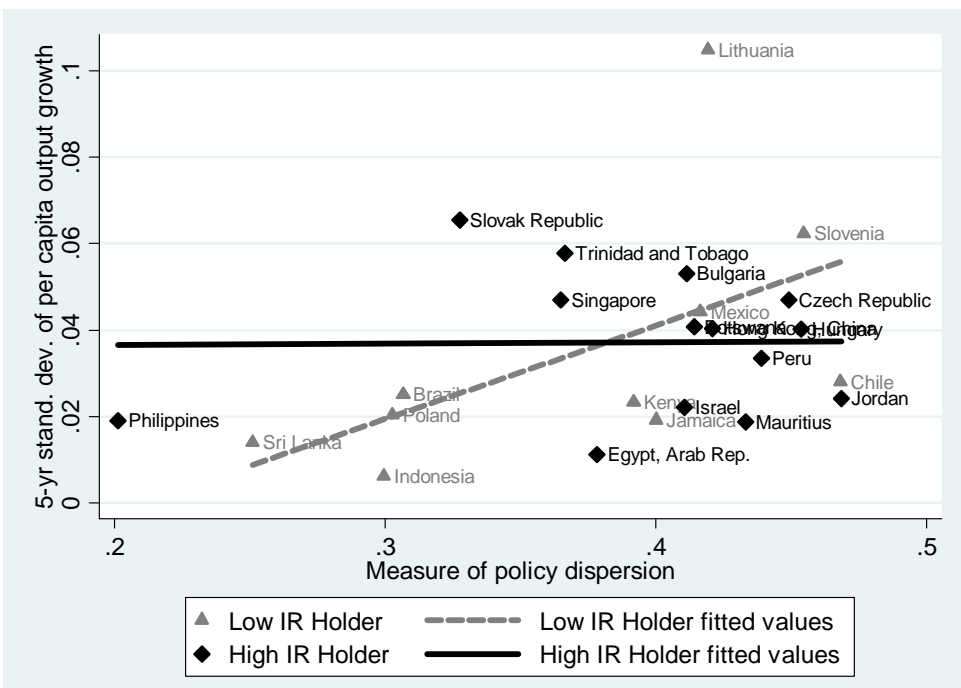

